\title{
KEJADIAN AKSI TERORIS DAN DAMPAKNYA PADA PERFORMA NILAI TUKAR DOLAR AMERIKA SERIKAT DAN PERFORMA IHSG
}

\author{
Vincentia Wahju Widajatun ${ }^{1}$, Nugi M. Nugraha ${ }^{2}$, Sakina Ichsani ${ }^{3}$ \\ ${ }^{1}$ Universitas Widyatama, Bandung \\ Email : vincentia.wahju@widyatama.ac.id \\ ${ }^{2}$ Universitas Widyatama, Bandung \\ Email : nugi.mohammad@widyatama.ac.id \\ ${ }^{3}$ Universitas Widyatama, Bandung \\ Email : sakina.ichsani@widyatama.ac.id
}

\begin{abstract}
ABSTRAK
Makalah ini berisi tinjauan komprehensif terhadap literatur tentang dampak kejadian terorisme terhadap performa IHSG. Terorisme merupakan suatu kejadian yang dilakukan oleh individu atau kelompok untuk melakukan serangan-serangan yang telah terkoordinasi dan bertujuan membangkitkan perasaan takut atau cemas terhadap sekelompok masyarakat yang mengakibatkan kerugian di suatu Negara. Dalam melakukan aksinya, pelaku terorisme seringkali menggunakan cara kekerasan ataupun militer untuk menyebarkan ketakutan atau teror pada masyarakat atau suatu Negara. Terjadinya serangan terorisme akan memberi dampak pada sektor investasi dan perekonomian di suatu Negara. Karena setelah terjadinya serangan terorisme tersebut, akan muncul ketidakstabilan politik dan keamanan di Negara tersebut. Penelitian ini bertujuan untuk meninjau hubungan terjadinya bencana dengan dampaknya terhadap performa nilai tukar terutama nilai tukar rupiah terhadap dolar Amerika Serikat dan performa pasar modal yang diwakili oleh IHSG. Makalah ini menggunakan penelitian deskriptif dan pendekatannya menggunakan literature review. Pada berbagai literatur menyebutkan aksi terorisme memiliki dampak ekonomi yang cukup luas terutama di Indonesia yang berdasarkan data Global Terorism Index 2017, skala dampak terorisme di Indonesia berada di level menengah dengan skor 4,55 dari skor tertinggi 10. Hasil review ini menunjukkan bahwa dari seluruh kejadian terorisme yang terjadi di Indonesia, hampir seluruhnya memberikan dampak negatif pada performa Indeks Harga Saham Gabungan (IHSG) dan nilai tukar rupiah terhadap mata uang asing.
\end{abstract}

Kata kunci: bencana, terorisme, nilai tukar dollar AS, IHSG.

\section{ABSTRACT}

This paper contains a comprehensive review of the literature on the impact of terrorism incidents on CSPI performance. Terrorism is an event carried out by individuals or groups to carry out attacks that have been coordinated and aim to arouse feelings of fear or anxiety towards a group of people that result in losses in a country. In carrying out its actions, terrorists often use violence or the military to spread fear or terror to the community or a State. The occurrence of terrorist attacks will have an impact on the investment sector and the economy in a country. Because after the terrorist attacks, political and security instability in the country will emerge. This study aims to review the relationship between the occurrence of disasters and their impact on the performance of the exchange rate, especially the exchange rate of the rupiah against the US dollar and the capital market performance represented by the CSPI. This paper uses descriptive research and its approach uses literature review. In various literatures mention terrorism has quite a broad economic impact especially in Indonesia which based on 2017 Global Terorism Index data, the scale of the impact of terrorism in Indonesia is at the middle level with a score of 4.55 from the highest score of 10. The results of this review indicate that of all incidents terrorism that occurred in Indonesia, almost all had a negative impact on the performance of the Composite Stock Price Index (CSPI) and the exchange rate of the rupiah against foreign currencies.

Keywords : disaster, terrorism, US dollar exchange rate, CSPI. 


\section{PENDAHULUAN}

\section{Latar Belakang}

Bencana umumnya disebabkan oleh natural and environment, ataupun tindakan manusia. Terjadinya bencana kerap kali sangat sulit diprediksi sehingga tingginya tingkat ketidakpastian menimbulkan dampak yang bencana menimbulkan kerugian besar terhadap bisnis karena bencana bisa menghancurkan aset terutama bangunan beserta isinya dalam sekejap. Aset perusahaan tidak hanya yang tercantum pada laporan neraca saja, karena data merupakan harga yang berharga pula bagi perusahaan.

UU No 24 Tahun 2007 menyebutkan bahwa bencana merupakan suatu peristiwa atau rangkaian peristiwa yang disebabkan, baik oleh faktor alam dan atau faktor non alam maupun faktor manusia sehingga mengakibatkan timbulnya korban jiwa manusia, kerusakan lingkungan, kerugian harta benda, dan dampak psikologis dan dapat mengancam serta mengganggu kehidupan dan penghidupan masyarakat.(http://www.bnpb.go.id/pengetahuan-bencana/definisidan-jenis-bencana).

Terorisme adalah salah satu dari sekian banyaknya jenis bencana yang didefinisikan oleh BNPB dan terorisme mampu menghentikan kegiatan perusahaan terutama dalam bidang investasi. Serangan terorisme mengakibatkan kerugian besar sala satunya kehilangan nyawa manusia. Kerugian besar lainnya yaitu kerugian harta benda dan juga kerugian kehilangan data perusahaan, namun terorisme merupakan risiko yang tidak dapat dihindari bila terjadi. Sehingga perusahaan perlu waktu untuk menyusun suatu rencana pemulihan yang tepat, dengan mempertimbangkan waktu dan biaya agar bisnis dapat tetap berjalan dengan semestinya.

Terorisme merupakan serangan-serangan terkoordinasi yang memiliki tujuan untuk membangkitkan perasaan takut atau cemas terhadap sekelompok mayarakat. Inti dari kejadian terorisme adalah menyebarkan rasa takut dan cemas di tengah kelompok tertentu untuk mencapai tujuan yang diinginkan para pelaku. Para pelaku selalu mengandalkan elemen kejahatan yang mengejutkan dan tiba-tiba sehingga mengakibatkan korban tidak memiliki kesempatan untuk membela diri. Dalam melakukan aksinya, pelaku terorisme seringkali menggunakan cara kekerasan ataupun militer. Berbeda dengan perang, aksi terorisme tidak tunduk pada tata cara peperangan, seperti waktu pelaksanaan yang selalu tiba-tiba dan target korban jiwa yang acak serta seringkali merupakan warga sipil. Meski demikian, terorisme sebenarnya tidak terbatas hanya pada cara kekerasan atau militer saja, melainkan juga cara-cara lainnya.

Terorisme merupakan kejahatan terhadap kemanusiaan (Crime Against Humanity), serta merupakan ancaman yang serius terhadap kedaulatan setiap negara karena terorisme sudah merupakan kejahatan yang bersifat internasional yang menimbulkan bahaya terhadap keamanan, perdamaian dunia serta merugikan kesejahteraan masyarakat perlu dilakukan pemberantasan secara terencana dan berkesinambungan sehingga hak asasi orang banyak dapat dilindungi dan dijunjung tinggi.

Fenomena terorisme belakangan ini semakin menguat seiring dengan menguatnya pula fenomena radikalisme. Radikalisme sendiri merupakan faham yang menggunakan unsur-unsur kekuatan dan kekerasan dalam mencapai tujuannya. Radikalisme merupakan cikal bakal lahirnya terorisme. Radikalisme merupakan suatu sikap yang mendambakan perubahan secara total dan bersifat revolusioner dengan menjungkirbalikkan nilai-nilai yang ada secara drastis lewat kekerasan (vilence) dan aksi-aksi yang ekstrem.

Orang atau kelompok radikal memiliki pandangan bahwa dalam mencapai tujuan-tujuannya harus menggunakan cara-cara yang radikal atau cepat. Perubahan yang ingin dicapai harus 
diwujudkan dengan segera dan untuk itu diperlukan kekerasan atau kekuatan. Penggunanaan kekuatan atau kekerasan diperlukan agar perubahan atau hasil yang dinginkan dapat segera dicapai. Hal inilah yang melatarbelakangi kenyataan berkembangnya radikalisme berbanding lurus dengan perkembangan terorisme.

Motif kepentingan dan kebutuhan pada tindak pidana terorisme merupakan fenomena dalam pergaulan antar kelompok untuk mendapatkan kekuasaan atau keuntungan materi, fanatisme kelompok akibat wawasan atau cara berfikir yang sempit dan tertutup. Pengelompokan bisa didasarkan atas kesamaan ras, etnis asal negara atau daerah, agama, gender atau kesamaan apapun status sosial yang disampaikan dalam bentuk kekerasan/kejahatan.

Terorisme dilakukan untuk melakukan teror supaya adanya perubahan dalam struktur politik, mematikan struktur yang telah ada, aksi teror juga dapat dijadikan suatu strategi perang yang pada saat-saat tertentu kadang-kadang efektif namun dengan memakan jumlah korban yang besar dan luas. Dari tahun ke tahun aksi terorisme menunjukan angka-angka yang tinggi dan aksi terorisme ini sudah sampai pada tingkat yang mengkhawatirkan yang tidak saja bagi negara tersebut tetapi juga dunia internasional.

Aksi-aksi terorisme ini tidak hanya menyebar secara geografis, sehingga jumlah kelompok yang beroperasional dan jumlah korban yang mati maupun yang luka akibat aksi-aksi tersebut bertambah besar pula, sebagai contoh korban dari berbagai aksi terorisme yang terjadi di Indonesia seperti bom di Legian, Kuta, Bali pada tanggal 12 oktober 2002, Gedung Bursa Efek Jakarta (BEJ) tahun 1999, kantor Kedutaan Besar Filipina, kantor BCA Jakarta Utara dan beberapa tempat lainnya, peledakan Hotel JW Marriott dan Hotel Ritz-Carlton di Mega Kuningan (17/7/2009) sedangkan aksi teror juga lebih sering terjadi di beberapa negara yang berpotensi menjadi sasaran aksi teroris.

\section{Rumusan Masalah}

Aksi-aksi terorisme yang terjadi di Indonesia mengakibatkan dampak bagi performa nilai tukar terutama nilai tukar rupiah terhadap dolar Amerika Serikat dan performa pasar modal yang diwakili oleh IHSG.

\section{Tinjauan Pustaka}

\section{Bisnis dan Bencana}

Bisnis akan terus berjalan apabila ada komponen-komponen yang mendukung kelangsungan dari bisnis tersebut. Komponen-komponen bisnis tersebut harus berinteraksi dan saling mendukung dalam berkelanjutannya suatu bisnis. Pusat dari komponen-komponen tersebut adalah manusia yang menjalankan komponen lainnya.

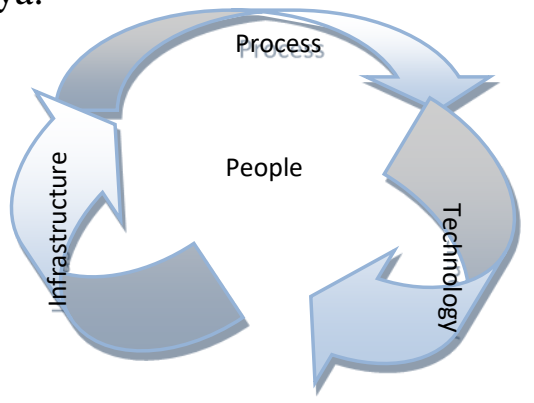

Gambar 1. How People, Process, Infrastructure and Technology Interact

Sumber: Business Continuity and Disaster Recovery Planning, Susan Snedaker, 2007, page 5 
Tiga komponen bisnis selain manusia (people) yaitu proses (process), teknologi (technology), dan infrastruktur (infrastructure). Pada gambar 1, komponen-komponen tersebut saling berinteraksi membentuk suatu siklus yang tidak berhenti dan manusia menjadi pusatnya, karena manusia yang menjaga berkelanjutannya siklus tersebut. Siklus ini akan berhenti jika salah satu komponen terjadi masalah. Bila infrastruktur seperti jalan penghubung antar kota terganggu seperti halnya jalan raya Yogyakarta-Magelang yang tergenang oleh lahar dingin mengakibatkan terputusnya arus kendaraan yang mengangkut bahan baku, barang jadi dan manusia sehingga menghambat pasokan bahan baku dan pasokan barang jadi di daerah lainnya. Dengan kurangnya bahan baku mempengaruhi proses produksi dari suatu pabrik dalam memproduksi barang. Pemulihan pasokan bahan baku tergantung dari bagaimana manusia mencari suatu solusi agar kebutuhan bahan baku tersebut dapat dipenuhi oleh perusahaan/pabrik tersebut.

Komponen-komponen bisnis dapat menjadi tidak berfungsi karena adanya hambatan yang disebabkan oleh natural and environment, human, infrastructure dan teknologi yang berkaitan dengan teknologi informasi.

Snedaker (2007) dalam bukunya yang berjudul Business Continuity and Disaster Recovery Planning, memberikan kategori hambatan bisnis berdasarkan penyebabnya yaitu Natural/ Environmental threats, Human-cause Threats, Infrastructure Threats dan IT-Special Threats. Hambatan yang terjadi bisa berupa disaster (bencana) yang mengakibatkan terhentinya suatu proses bisnis yang menimbulkan kerugian besar bagi perusahaan.

Bencana dapat terjadi tanpa diduga dan tidak bisa dihindari dan memberikan dampak yang sangat besar baik kepada perusahaan, masyarakat, ekonomi, sosial, pemerintah negara yang mengalami bencana. Oleh karena itu perlu diperhatikan apakah dampak dari bencana dapat berakibat terhentinya bisnis dan tidak dapat dilanjutkan atau bisnis masih bisa dilanjutkan dengan pemulihan bisnis. Sneaker (2007) membagi strateri mitigasi menjadi 4 dan untuk situasi bencana merupakan situasi yang tidak dapat dihindari yaitu Risk acceptance; perusahaan menerima risiko tanpa melakukan hal-hal pencegahan karena sulitnya menghindari risiko tersebut.

Untuk mencegah hal tersebut sebaiknya perusahaan menyiapkan perencanaan untuk business continuity and disaster recovery; Risk avoidance; menghindari risiko yang mungkin terjadi. Perusahaan melakukan persiapan sebelum terjadinya bencana, misalnya pembelian perahu karet untuk perusahaan yang berada di wilayah banjir. Strategi ini memiliki biaya tinggi di awal; Risk limitation; Data perusahaan merupakan suatu harta yang penting yang perlu dijaga agar tidak hilang, untuk mencegah hilangnya data maka data tersebut dibuatkan suatu backup data yang secara terus menerus di up date sepanjang berlangsungnya suatu bisnis; Risk transference; melibatkan pihak lain untuk menanggung risiko.dan biaya di awal tinggi kemudian biaya menjadi rendah. 


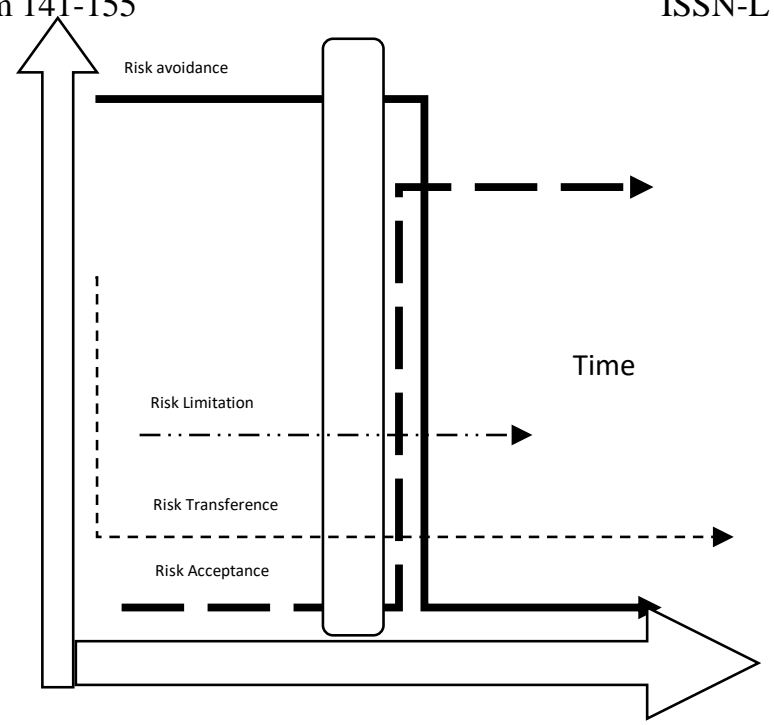

Gambar 3. Cost vs Time for risk mitigation Strategies

Sumber: Business Continuity and Disaster Recovery Planning, Susan Snedaker, 2007, page 263

Untuk mencegah hal tersebut sebaiknya perusahaan menyiapkan perencanaan untuk business continuity and disaster recovery. Pemulihan setelah terjadi bencana membutuhkan waktu dan biaya. Makin cepat pemulihan dari bencana maka semakin cepat bisnis dapat beroperasi kembali. Pemulihan yang cepat terkait dengan biaya yang dikeluarkan oleh perusahaan saat dilakukannya mitigasi. Gambar 3 memperlihatkan hubungan antara biaya dan waktu serta strategi mitigasi yang digunakan oleh perusahaan. Pada strategi risk acceptance biaya yang dikeluarkan setelah kejadian meningkat tinggi, dan akan terus tinggi bila tidak ada pemulihan yang dilaksanakan secara terencana dengan baik.

\section{Bisnis dan keberlanjutannya}

Bencana terjadi pada saat yang tidak terduga, sehingga mengakibatkan berhentinya suatu proses bisnis. Sehingga perusahaan mempersiapkan suatu pencegahan dan pemulihan dalam bentuk business continuity and disaster recovery plan. Dengan langkah awal dalam membuat business continuity and disaster recovery plan adalah dengan melakukan risk assessment dengan melihat ancaman-ancaman terjadinya risiko. Setiap kemungkinan dilakukan perhitungan biaya yang mungkin dikeluarkan oleh perusahaan bila perusahaan tidak memiliki business continuity and disaster recovery plan.

Business continuity and disaster recovery planning bagi tiap-tiap peristiwa berbeda. Berikut ini merupakan suatu bentuk Business continuity and disaster recovery planning untuk ITCP prosedur. Dapat dilihat pada gambar 4 bentuk dari ITCP standard prosedur untuk disaster recovery plan.

ITCP Procedural Standard for Disaster Recovery Plans mempunyai empat stage yang terdiri dari enam tahapan.

1. Stage pertama yaitu pengumpulan informasi dari dua sumber yang asli mengenai empat critical factor (financial, operation, reputation, regulation) dengan questionnaire (BIA,REC,PIM) di tahap yang pertama pada tahap ke dua dilakukan analisis faktor.

2. Stage kedua melakukan risk analysis yang menghasilkan mapping 4 factors yang dibagi dalam critical levels berdasarkan informasi dari dalam dan dari luar. 
3. Stage ketiga; Mapping critical levels yang telah ditetapkan pada stage kedua diklasifikasikan critical level mulai dari crisis, major, significant sampai insignificant. Dan ditahap berikutnya terdapat recovery strategy yang membuat prioritas critical level.

4. Stage ke empat; membuat dan memberikan rekomendasi suatu keputusan.

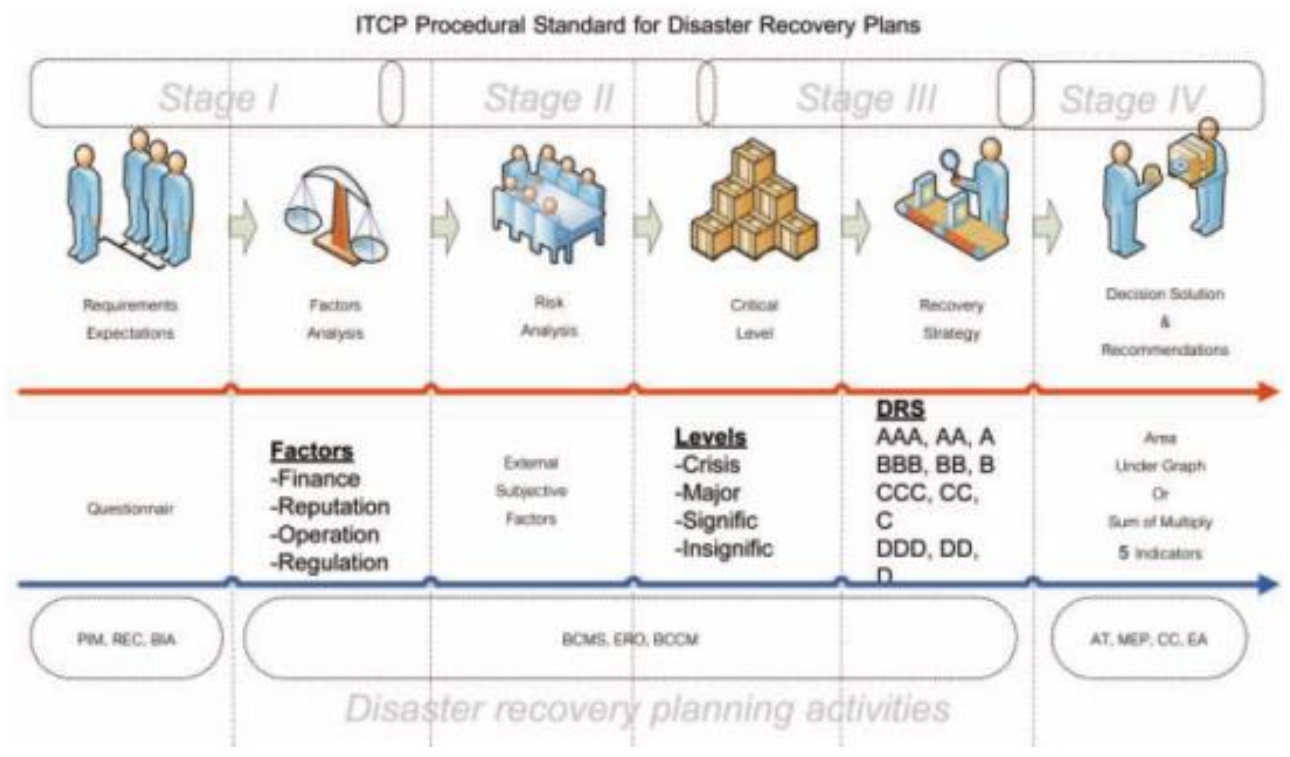

Gambar 4. ITCP Procedural Standard for Disaster Recovery Plans

Sumber: Optimal Strategic Decision For Disaster Recovery, Montri Wiboonratr, and Kitti Kosavisutte, 2009, International Journal of Management Science and Engineering Management, Vol. 4 (2009) No. 4, pp. 260-269

Stage I memberikan gambaran mengenai risiko dan faktor-faktor yang mendapatkan dampak dari peristiwa terjadinya suatu bencana. Faktor financial, factor reputation, factor operation dan factor regulation. Semakin besar tingkatan level krisis yang tergambar pada stage III, maka semakin cepat keputusan untuk pemulihan dari bencana.

Ada beberapa tahapan proses recovery yang diuraikan oleh Nathaniel Forbes dimulai dari preparedness, response dan recovery.

Preparedness dibagi menjadi 2 sektor yaitu sector public dan sector private company. Hal-hal yang diperhatikan dalam sector public adalah keselamatan dari masyarakat yang berada di wilayah berbahaya, memperhitungan mengenai hambatan yang mungkin terjadi saat melakukan recovery. Pemerintah membuat program sosialisasi dan training bagi masyarakat dalam hal tindakan pertama saat terjadinya bencana, termasuk peralatan-peralatan yang mendukung untuk tindakan pertama pertama tersebut. Penggunaan alat-alat tersebut dibuatkan suatu training khusus bagi masyarakat. Selain hal tersebut perlunya pemerintah mempunyai staff yang mengerti dan mampu memberikan informasi bagi masyarakat mengenai bencana tersebut.

Seperti pada gambar 5 yaitu bagan tentang incident command system, dalam recovery terdapat suatu sistem yang menyeluruh termasuk dalam hal organisasi sehingga adanya kejelasan dalam pemberian komando saat pelaksanaan recovery. 


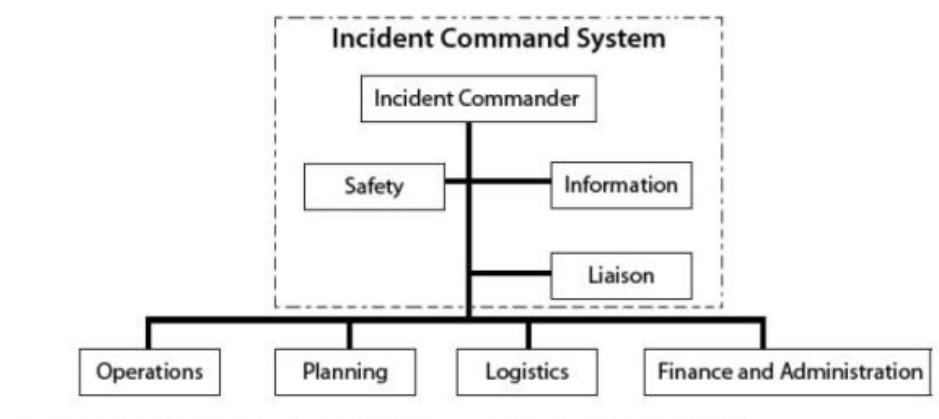

Source: http://www.osha.gov/SLTC/etools/ics/what_is_ics.htm/\#Command

\section{Gambar 5. Incident Command System}

Response dibagi pula dari 2 sektor yaitu sector public dan sector private dengan memperhatikan hal-hal yang berkaitan dengan pemulihan dari bencana tersebut seperti adanya tim medis, adanya recovery system di bidang IT.

Recovery memperhatikan mengenai pengamanan daerah bencana, pelaksanaan proses pemulihan wilayah yang terkena dampak bencana dengan membangun tempat pemukiman baru misalnya (untuk public sector). Pada private sector pemulihan dilakukan agar proses bisnis dapat berjalan normal kembali seperti sebelum terjadinya bencana.

Dari tiap-tiap tahap tersebut dibutuhkan manusia yang kompeten agar pemulihan berjalan cepat, tepat dan biaya yang sesuai. Faktor manusia masih merupakan faktor penentu dari keberhasilan pemulihan seperti pada gambar 1, yang memperlihatkan bahwa manusia (people) merupakan pusat dari komponen-komponen bisnis. Hal-hal yang diperhatikan pada tahapan preparation, response and recovery. (Forbes, Nathaniel, 2009)

Pada bisnis saat ini tidak lepas dari teknologi informasi, sehingga pemulihan pada bidang teknologi informasi juga menjadi suatu bagian yang penting. Sneader (2007) memberikan gambaran untuk pemulihan dalam bidang IT dimulai dengan mempersiapkan perlengkapan agar data dapat di backup seperti pada gambar 6 yang memperlihatkan waktu pemulihan data dari sebelum terjadinya disaster sampai system IT dapat beroperasi normal kembali.

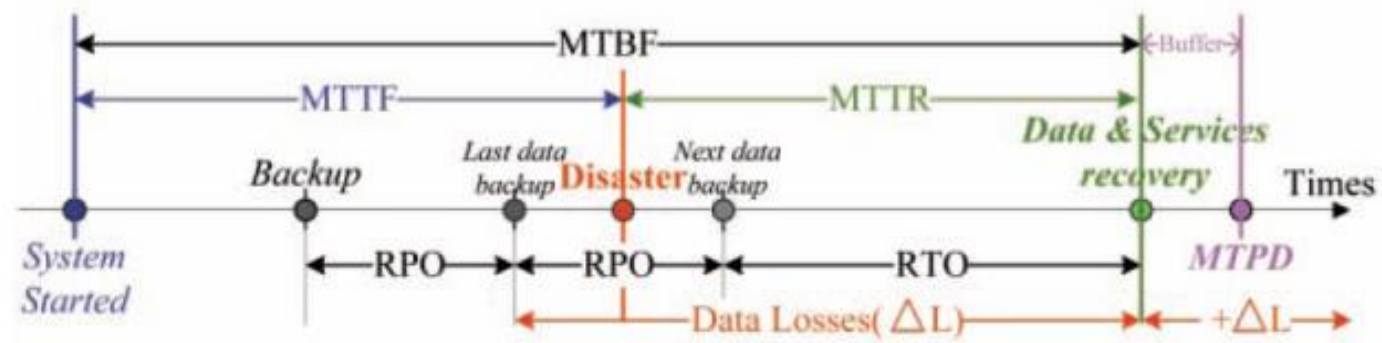

Gambar 6. Chronological time domain

Sumber: Business Continuity and Disaster Recovery Planning, Susan Snedaker, 2007

Pada gambar 6, kita mengenal istilah-istilah berikut :

- Recovery Point Objective (RPO): RPO dilakukan rutin sesuai dengan prosedur yang ada dalam perusahaan untuk me-resume proses dari transaksi. 
- Recovery Time Objective (RTO): Suatu periode waktu yang digunakan untuk memulihkan kegiatan bisnis yaitu waktu yang terpakai mulai terjadinya bencana hingga bisnis berjalan normal kembali.

- Mean Time between Failures (MTBF): Siklus waktu rata-rata antara kegagalan dan perbaikan.

- Mean Time to Failure: Rata-rata waktu dimana sistem tidak berfungsi

- Mean Time to Repair (MTTR): Rata-rata waktu untuk memperbaiki sistem, atau lama downtime sistem sebelum pulih pada operasi normal..

- Maximum Tolerable Period of Disruption (MTPD): toleransi waktu terhadap gangguan yang terjadi dikarenakan adanya bencana.

- Data Availability: Suatu proses sistem penyimpanan data yang meminimalkan kerugian kehilangan data. Hal ini terjadi jika semua / aktif siaga / paralel situs dalam suatu korporasi memiliki salinan data penting. Hal ini dapat dicapai dengan mereplikasi data antara lokasi primer dan sekunder. Data asli harus direproduksi dalam waktu yang dapat diterima yang diperlukan untuk memenuhi kebutuhan bisnis MTPD.

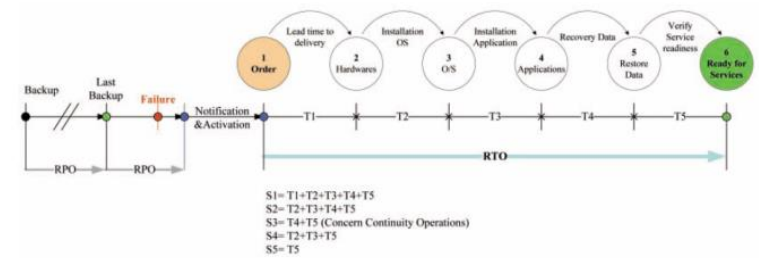

Gambar 7. Chronological strategic recovery time (SRT) of each pattern

Sumber: Business Continuity and Disaster Recovery Planning, Susan Snedaker, 2007

Dari kronologi pada gambar 6, diperjelas dengan kronologi dari gambar 7 yang memperhitungkan waktu yang digunakan pada saat recovery. RTO terbagi menjadi 5 waktu yang dibagi-bagi menurut prioritas pekerjaan yaitu:

- T1 adalah waktu setelah insiden bencana yang dipakai untuk mengetahui peralatan IT yang dibutuhkan mulai dari pemesanan hingga mendapatkan peralatan tersebut.

- T2 adalah waktu yang digunakan untuk menginstal sistem operasi.

- T3 adalah waktu yang digunakan untuk menginstal layanan aplikasi

- T4 adalah waktu yang digunakan untuk memulihkan data kembali ke sistem penerimaan sebagai RPO.

- T5 adalah waktu yang digunakan untuk memverifikasi kesiapan layanan untuk end-user dan atau operator.

Keseluruhan waktu adalah S5 dimana semua hardware yang dibutuhkan telah siap digunakan dan data yang dikumpulkan setelah terjadinya disaster dipersiapkan untuk diolah kembali.

\section{Terorisme Salah Satu Penyebab Disaster}

Bencana yang berasal dari alam (natural threats) seperti gempa bumi, meletusnya gunung berapi, tsunami tidak bisa dihindari namun dengan kemajuan teknologi saat ini telah diciptakan peralatan yang mampu memantau dan memprediksikan terjadinya bencana tersebut. Untuk memantau gempa bumi Indonesia mempunyai lembaga yang selalu memberikan informasi yaitu Badan Meteorologi Klimatologi dan Geofisika (BMKG). BMKG juga mengeluarkan info peringatan tsunami. Data gempa ini juga akan diintegrasikan dengan data dari peralatan sistem 
peringatan dini lainnya (GPS, BUOY, OBU, Tide Gauge) untuk memberikan konfirmasi apakah gelombang tsunami benar-benar sudah terbentuk. Bencana diklasifikasikan menjadi tiga jenis: alami, man-mades, dan bencana hibrida. Dipercayai bahwa ketiga jenis bencana tersebut mencakup semua peristiwa bencana. Tidak ada definisi bencana yang diterima secara universal. Beberapa kriteria diusulkan untuk mendefinisikan bencana. Memahami definisi, kriteria, dan jenis bencana membantu peneliti dan lembaga dalam klasifikasi yang tepat, rekaman yang baik, dan analisis bencana yang lebih baik. Bencana memiliki karakteristik dan dampak yang berbeda; namun, bencana memiliki elemen yang sama, yaitu keparahannya. (Shaluf, IM. 2007).

Penyebab lain dari bencana yang saat ini sering terjadi adalah serangan dari teroris yang ditujukan pada kegiatan bisnis. Hal tersebut dapat dilihat dari serangan teroris pada tahun 20022018, wilayah yang diserang merupakan pusat kegiatan yang melibatkan banyak orang dimulai dari Bom Bali 1 hingga Serangan Teroris di Surabaya. Akibat tidak langsung yang dirasakan oleh dunia bisnis karena terjadinya serangan teroris berupa meningkatnya transactions costs, declines in buyer demand, terganggunya supply chain. Untuk mengantisipasi hal tersebut keberadaan business continuity and disaster recovery planning merupakan suatu persiapan dalam menghadapi ketidakpastian terutama yang disebabkan oleh serangan teroris. Pemulihan/ recovery dari bencana dilakukan secara bersama-sama dengan antara pemerintah, public sector, private sector, sehingga pemulihan dapat berlangsung cepat, tepat dan baik. Ada perbedaan aktivitas disaster recovery planning dan business continuity planning, yang terletak pada goals dan outcomes-nya. DRP lebih focus pada melakukan recovery pada IT system sedangan BCP lebih pada aktivitas bisnis. (Cervone, H.F, .2017)

Adanya kejadian terorisme dapat mengakibatkan jaringan internet, listrik dan computer tidak dapat beroperasi. Dengan menerapkan DRP dan BCP dapat mempercepat pemulihan perusahaan sehingga perusahaan memerlukan mainframe computers server systems yang memperhatikan keamanan data termasuk data perdagangan di bursa saham. Dengan adanya perlindungan dari perusahaan terhadap data maka dapat mengurangi risiko dari bencana yang timbul. (Steve M. Hawkins. David C. Yen .David C. Chou. 2000.) Risiko dari rusaknya system IT adalah hilangnya koneksi melalui jaringan internet dan jaringan di dalam perusahaan saat ini, yang sebagian besar sistemnya menggunakan IT system. Dari penelitian di Abu Dhabi yang Mayoritas responden melaporkan memiliki DRP, dan sejumlah besar responden melaporkan bahwa manajemen puncak mereka sangat berkomitmen terhadap DRP mereka. Karyawan pada umumnya menyadari peran mereka dan keberadaan DRP.

Saat ini teknologi IT merupakan teknologi yang terus berkembang dan perusahaan membutuhkan keberadaan teknologi IT dalam menjalankan bisnisnya. Kemampuan perusahaan untuk melakukan recovery pada IT setelah terjadi bencana merupakan salah satu indicator perusahaan dalam menerapkan penanggulangan keadaan darurat.

Dengan fenomena seringnya terjadi serangan bom di Indonesia, perusahaan-perusahaan yang berdomilisi di Indonesia diharapkan dapat menerapkan DRP dan BCP sehingga dapat memberikan kepastian bagi para investor yang berdampak pada IHSG. Dari uraian diatas maka peneliti mengamati dari data sekunder mengenai kejadian serangan dan efeknya terhadap kurs mata uang asing serta IHSG.

\section{METODE PENELITIAN}

\section{Analisis Deskriptif}


Metode penelitian deskriptif menurut Sugiyono (2016:35). Metode deskriptif adalah penelitian yang dilakukan untuk mengetahui nilai variabel mandiri, baik satu variabel atau lebih tanpa membuat perbandingan atau menghubungkan dengan variable lain (variabel mandiri adalah variabel yang berdiri sendiri, bukan variabel independen karena jika independen selalu dipasangkan dengan variable dependen.

\section{Literature Review}

Metode dalam penulisan ini dengan meninjau secara komprehensif beberapa literatur tentang terjadinya bencana yang disebabkan oleh kejadian terorisme. Sebagian besar penelitian bersifat empiris dan sebagian besar studi berfokus pada dampak pada investasi yang dirasakan Indonesia karena bencana yang disebabkan serangan terorisme.

\section{HASIL DAN PEMBAHASAN}

Terjadinya bencana di suatu negara yang salah satunya disebabkan oleh kejadian terorisme akan memberi dampak pada sektor investasi dan ekonomi di negara tersebut. Hal ini dikarenakan setelah terjadinya bencana tersebut, muncul ketidakstabilan politik dan keamanan di negara tersebut. Dari kejadian terorisme yang terjadi di Indonesia, hampir seluruhnya memberikan dampak negatif pada performa Indeks Harga Saham Gabungan (IHSG) dan nilai tukar rupiah terhadap mata uang asing. Berikut ini adalah performa IHSG dan nilai tukar mata uang rupiah terhadap mata uang asing khususnya USD setelah terjadinya kejadian terorisme di beberapa wilayah di Indonesia:

- Bom Bursa Efek Jakarta

Peristiwa pengeboman di BEJ pada tanggal 13 September 2000 memberikan dampak pada performa IHSG dan nilai tukar rupiah pada saat bursa kembali dibuka pada tanggal 18 September 2000. Mata uang rupiah terdepresiasi ke Rp 8,775 per USD dan IHSG turun sebesar $7 \%$.

- Bom Malam Natal di beberapa Gereja yang tersebar di sejumlah kota di Indonesia.

Bom pada malam natal pada tahun 2000 memberikan dampak pada performa IHSG dan nilai tukar rupiah. Pada tanggal 26 Desember 2000, rupiah melemah sebesar $1.51 \%$ ke nilai Rp 9,400 per USD dan rupiah kembali melemah sebesar 1.81\% ke nilai Rp 9,570 per USD pada tanggal 28 Desember 2000. Sesudah libur panjang, bursa dibuka dengan pelemahan di IHSG. Pada tanggal 2 dan 3 Januari 2001, IHSG melemah sebesar 1,47\% dan 1,07\%.

- Bom Plaza Atrium Senen, Jakarta Pusat

Bom yang terjadi di Plaza Atrium Senen, Jakarta Pusat memberikan dampak yang negatif pada nilai tukar dan performa IHSG. Nilai tukar rupiah melemah $0.37 \%$ ke nilai Rp 8,600 per USD dan IHSG ditutup melemah $0.97 \%$.

\section{- Bom Bali I}

Dampak yang paling buruk bagi investasi dan perekonomian di Indonesia karena terjadinya peristiwa terorisme adalah peristiwa Bom Bali 2002 (Bom Bali I). Pada peristiwa itu 192 orang meninggal dunia dan 422 fasilitas publik rusak. Sesudah kejadian Bom Bali I, nilai tukar rupiah turun hinggal lebih dari 3\% ke nilai Rp 9,300 per USD. Selain itu performa IHSG turun hingga lebih dari $10 \%$, yang merupakan performa terburuk IHSG yang pernah tercatat.

\section{- Bom JW Marriott}


Bom yang terjadi di hotel JW Marriot mengakibatkan 11 orang meninggal dunia. Nilai tukar rupiah terhadap USD pada hari itu ditutup dengan pelemahan sebesar $1.35 \%$ ke nilai Rp 8,600 per USD dan performa IHSG turun hingga lebih dari 3\%

- Bom Kedubes Australia

Peristiwa ini terjadi pada tanggal 09 September 2004 di depan pintu kedutaan besar Australia untuk Indonesia. Kejadian ini menjadi perhatian besar di nasional dan internasional, sehingga mengakibatkan nilai tukar rupiah terkoreksi sebesar $-0.09 \%$ dan IHSG terkoreksi sebesar $0.82 \%$.

- Bom Bali II

Pada tanggal 01 Oktober 2005, kembali terjadi aksi terorisme di Bali yang sering disebut Bom Bali II. Bom Bali II mengakibatkan 23 orang meninggal dunia. Namun performa IHSG tidak menunjukan arah negatif seperti halnya Bom Bali I. Performa IHSG saat itu justru mengalami penguatan $2.67 \%$ pada perdagangan 03 Oktober 2005 atau ke lever 1,083.41. hal ini menunjukan bahwa Bom Bali II tidak memberi kekhawatiran bagi para investor.

- Bom Jakarta 2009 (Hotel JW Marriott dan Ritz Carlton)

Pada tanggal 17 Juli 2009, Hotel JW Marriot kembali diguncang bom. Pada kejadian terorisme kali ini, teroris juga membom hotel Ritz Carlton. Akibatnya adalah IHSG ditutup melemah $0.55 \%$ dan nilai tukar rupiah melemah menjadi Rp 10,250 per USD.

- Bom Bunuh Diri di GBIS Kepunton Solo

Aksi terorisme ini mengakibatkan pelaku meninggal dunia dan satu orang anggota polisi mengalami luka-luka. Akibatnya adalah nilai tukar rupiah terhadap US Dollar ditutup melemah $3.19 \%$ ke nilai Rp9,050 per USD.

Aksi pengeboman saat itu menewaskan pelaku dan 1 anggota kepolisian mengalami lukaluka. Rupiah ditutup melemah hingga 3,19\% ke Rp9.050/US\$. Pelemahan sebesar itu bahkan nyaris menyamai turunnya rupiah pasca kejadian Bom Bali 2002. Akan tetapi sehari setelah kejadian tersebut, IHSG ditutup melemah hingga lebih dari 3\%. Kejadian itu terjadi saat cuti bersama Lebaran tahun 2016. Beberapa hari kemudian di tanggal 11 Juli 2016 IHSG dibuka di level 5021.24 menguat dibandingkan dengan penutupan hari bursa sebelumnya dan ditutup menguat pada sore harinya ke level 5069.02, naik 0.95\%. Bahkan, beberapa hari berikutnya IHSG masih melanjutkan tren penguatan didorong oleh sentimen tax amnesty yang diresmikan pada akhir Juni 2016. Dapat disimpulkan bahwa aksi terorisme saat itu tidak berpengaruh terhadap pasar saham.

- Bom dan Baku Tembak di Sarinah, Jakarta

Kejadian bom di wilayah Sarinah Thamrin dimulai dengan ledakan bom di Starbucks Sari Indah dan ledakan di pos polisi gedung Sarinah Thamrin. Baku tembak terjadi antara polisi dan teroris hingga siang hari. Akibatnya adalah nilai tukar rupiah melemah $0.61 \%$ ke Rp 13,905 per USD dan IHSG melemah $0.53 \%$. namun pada akhir hari, IHSG ditutup menguat $0.45 \%$

- Bom Bunuh Diri di Gereja Surabaya

Pada bulan Mei 2018 terjadi serangkaian aksi bom bunuh diri di Surabaya, yaitu di 3 gereja di Surabaya, di rusun di Sidoarjo dan di Polrestabes Surabaya. Akibatnya adalah pada tanggal 14 Mei 2018 IHSG sempat turun lebih dari 1\% namun pada akhir perdagangan IHSG kembali menguat. Penurunan ini cenderung diakibatkan oleh faktor psikologis pasar. 
Menurut artikel yang ditulis oleh Ekonom Bank Federal Reserve St. Louis Subhayu Bandyopadhyay, dan Profesor Ekonomi American University of Sharjah, Uni Emirat Arab Javed Younas menyebutkan aksi terorisme memiliki dampak ekonomi yang cukup luas. Terorisme merupakan serangan-serangan terkoordinasi yang bertujuan untuk membangkitkan perasaan teror terhadap sekelompok masyarakat. Namun inti dari terorisme itu adalah untuk menciptakan rasa kerentanan bagi individu atau bisnis. Berdasarkan data Global Terorism Index 2017, skala dampak terorisme di Indonesia berada di level menengah dengan skor 4,55 dari skor tertinggi 10. Dari 130 negara yang dipantau, Indonesia berada di peringkat 42. Di kawasan ASEAN, negara yang skala dampak terorismenya lebih besar dari Indonesia di antaranya Filipina dengan skor 7,12. Lalu, Thailand 6,6, dan Myanmar 4,95. Masing-masing negara itu berada di peringkat ke11, ke-16, dan ke-37. Insiden bom membuat reaksi negatif pasar modal dengan paramater indeks yang melemah pasca kejadian untuk jangka pendek. Namun, yang dikhawatirkan peristiwa ledakan bom justru dinilai berpotensi mempengaruhi ekonomi, terutama terhadap iklim investasi dan sektor pariwisata.

Terjadinya bencana yang berupa serangan terorisme mengakibatkan penurunan IHSG dan pelemahan nilai tukar rupiah terhadap mata uang asing. Hal ini merupakan reaksi negatif investor yang seketika merespon serangan terorisme, tetapi hal ini tidak belangsung lama. pelemahan ini tidak mempengaruhi laju pertumbuhan pasar modal, hal ini dikarenakan efek dari terorisme ini hanya bersifat sementara. Kemampuan pemerintah dalam menangani serangan terorisme ini sudah menjadi hal yang menenangkan para investor, sehingga para investor tidak terlalu khawatir dan tetap berinvestasi di Indonesia. Penurunan IHSG dan pelemahan nilai tukar tidak hanya disebabkan oleh aksi terorisme, namun juga merupakan akibat dari kekhawatiran investor global atas rencana Amerika Serikat menaikan suku bunganya. Hal ini terlihat dari indeks harga saham dari negara lain pun mengalami pelemahan.

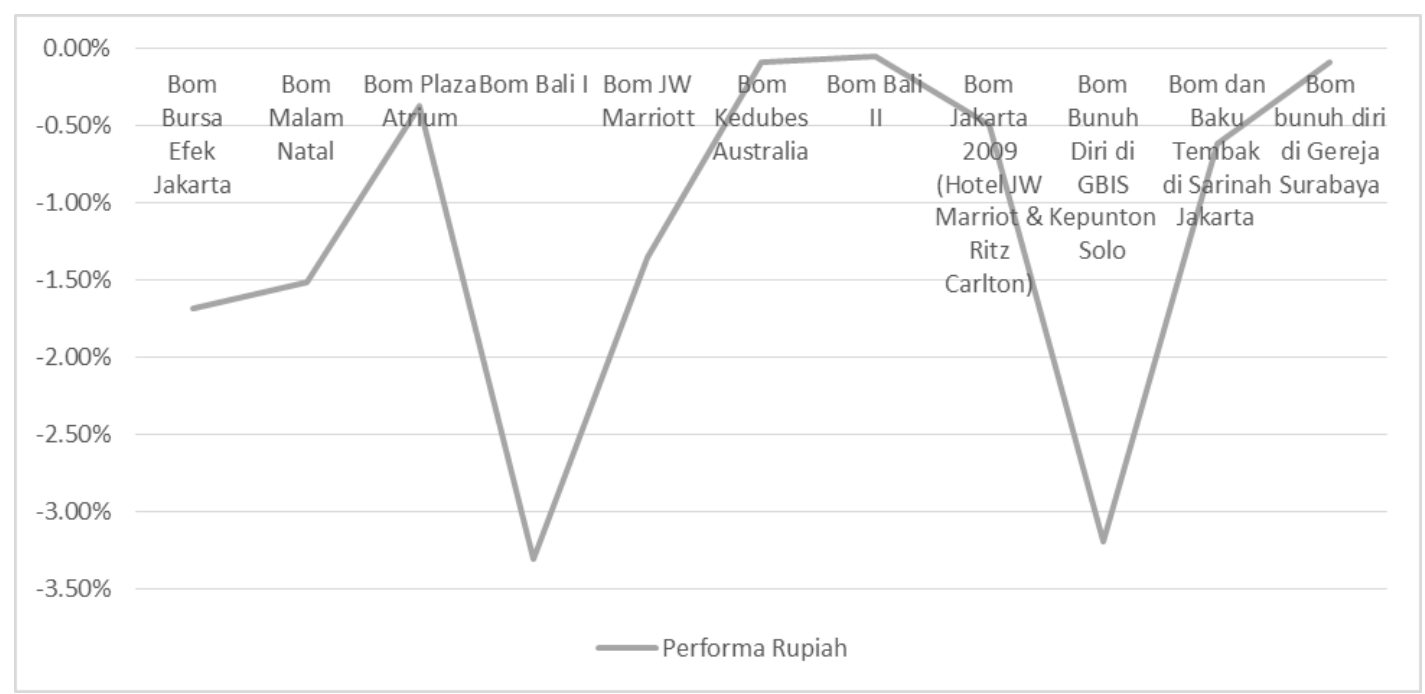

Gambar 8. Performa Rupiah

Dari gambar 8 memperlihatkan pada kejadian bom Bali 2002 terjadi penurunan rupiah yang sangat besar yang semula turun $0,05 \%$ menjai $-3,4 \%$, dan terjadi lagi saat bom bunu dir di GBIS Kepunton Solo. Dengan adanya peristiwa terorisme tersebut proses perencanaan dalam penanggulangan bencana masih belum maksimal terbukti dengan terjadinya penurunan kembali pada peristiwa bom bunuh diri Solo. 


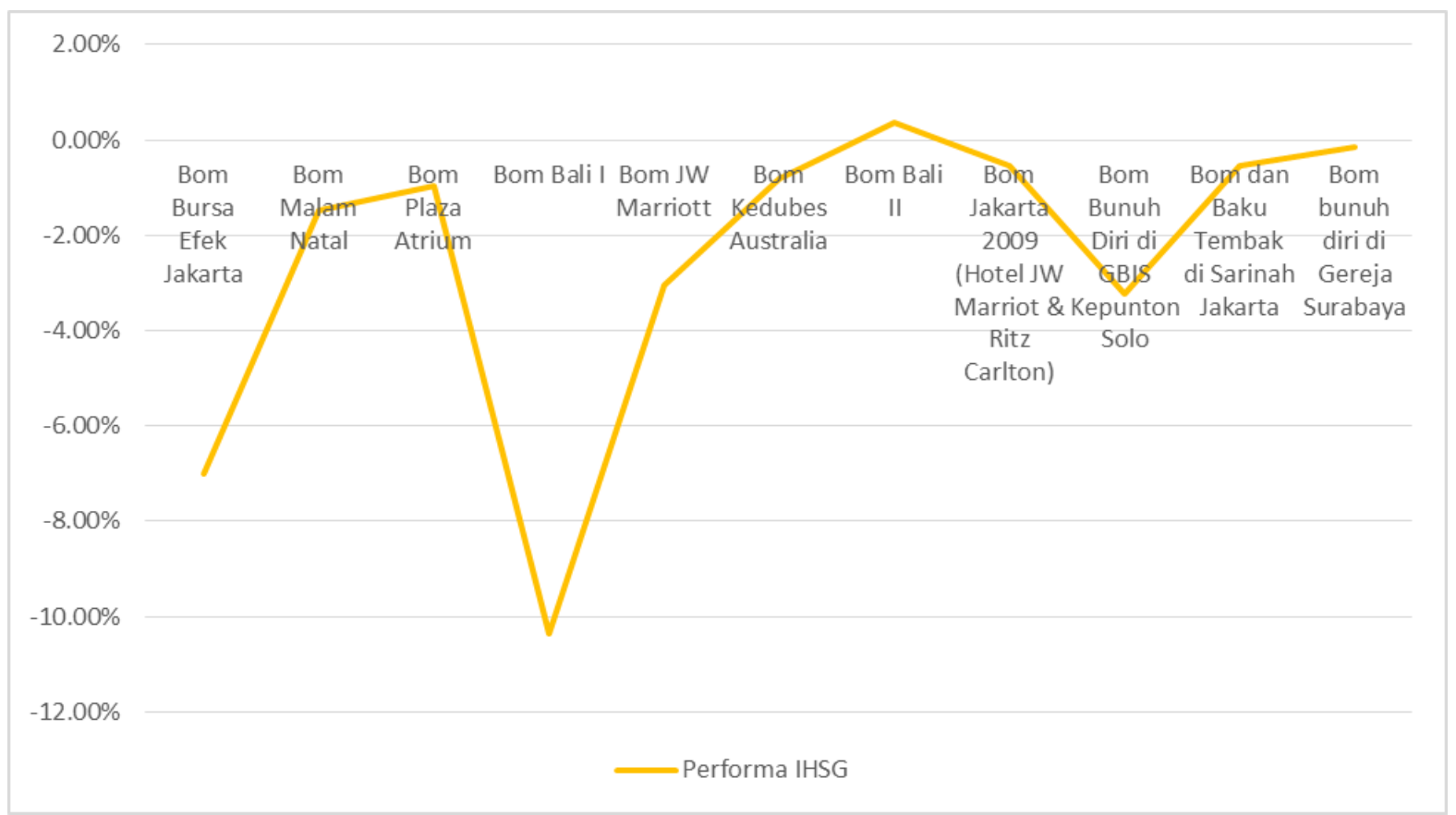

Gambar 9. Performa IHSG

Gambar 9 menunjukkan adanya penurunan performa IHSG pada peristiwa bom Bali I dan peristiwa bom bunuh diri di GBIS Kepunton Solo, seperti halnya pada penurunan nilai tukar rupiah terhadap USD. Walaupun nilai untuk penurunan IHSG lebih besar saat peristiwa bom Bali I sedangan penurunan pada nilai tukar lebih besar pada peristiwa bom bunuh diri di Solo. Penurunan IHSG ini lebih dipicu oleh kebijakan pemerintah mengenai tax amnesty.

Dengan adanya fluktuasi pada nilai tukar dan IHSG karena adanya kejadian terorisme maka perusahaan perusahaan di Indonesia memerlukan recovery plan yang tepat. Untuk Bank, OJK telah mengeluarkan Peraturan Otoritas Jasa Keuangan Nomor 14 /POJK.03/2017 Tentang Rencana Aksi (Recovery Plan) Bagi Bank Sistemik.

\section{KESIMPULAN DAN SARAN KESIMPULAN}

Berdasarkan penelitian yang sudah dilakukan terjadinya bencana di suatu negara yang salah satunya disebabkan oleh kejadian terorisme akan memberi dampak pada sektor investasi dan ekonomi di negara tersebut. Hal ini dikarenakan setelah terjadinya bencana tersebut, muncul ketidakstabilan politik dan keamanan di negara tersebut. Dari kejadian terorisme yang terjadi di Indonesia, hampir seluruhnya memberikan dampak negatif pada performa Indeks Harga Saham Gabungan (IHSG) dan nilai tukar rupiah terhadap mata uang asing. Disaster recovery plan lebih mempersiapkan pada kecepatan informasi dan keamanan yang disiapkan oleh pemerintah terutama setelah aktifnya tim densus 88 . Pencegahan terjadinya terorisme di Indonesia lebih cepat dengan digagalkannya beberapa rencana aksi terorisme. Dengan keamanan negara yang baik maka aliran dana investasi ke bursa efek Indonesia tidak mengalami fluktuasi yang besar demikian pula nilai tukar rupiah.

Peristiwa tidak terduga mengakibatkan penurunan mata uang rupiah terhadap mata uang asing terutama USD yang merupakan mata uang yang digunakan untuk transaksi perdagangan dengan negara lain baik sector swasta maupun BUMN. Demikian pula dengan indeks harga saham 
gabungan mengalami penurunan saat terjadinya kejadian terorisme, terutama kejadian Bom Bali I dan kejadian bom bunuh diri di GBIS Solo.

\section{SARAN}

Perlu pemulihan bisnis terkait dengan kejadian bencana dengan pembuatan rencana untuk mengatasi secara cepat dengan menggunakan strategi yang tepat seperti strategy recovery time. Strategi tersebut merupakan bagian dari disaster recovery plan yang memperhatikan pula kronologis kejadian, serta keterlibatan dari seluruh pengambil keputusan. Disaster recovery plan lebih mempersiapkan pada kecepatan informasi dan keamanan yang disiapkan oleh pemerintah terutama setelah aktifnya tim densus 88. Pencegahan terjadinya terorisme di Indonesia lebih cepat dengan digagalkannya beberapa rencana aksi terorisme.

Diharapkan untuk penelitian selanjutnya menambahkan faktor-faktor lain terkait terorisme yang akan berdampak pada sektor investasi dan perekonomian di suatu negara. Perlunya penanganan khusus untuk mengantisipasi dampak yang terjadi karena bencana yang salah satunya muncul karena terjadinya kejadian terorisme. Dan perlu uraian yang lebih detail dari setiap literatur yang melakukan penelitian sejenis.

\section{Ucapan Terima Kasih (Acknowledgement)}

Ucapan terima kasih kepada Direktorat Riset dan Pengabdian Masyarakat Direktorat Jenderal Penguatan Riset dan Pengembangan Kementerian Riset, Teknologi, dan Pendidikan Tinggi yang telah membiayai penelitan tersebut. Dengan Kontrak Penelitian Nomor: 110/SP2H/PPM/DRPM/2019, tanggal 8 Maret 2019

\section{REFERENSI}

Cervone, H.F, .2017. Disaster recovery planning and business continuity for informaticians. Digital Library Perspectives Vol.33No.2,2017 pp. 78-81

El-Temtamy, O, Majdalawieh, M, and Pumphrey, L. 2016. Assessing IT disaster recovery plans The case of publicly listed firms on Abu Dhabi/UAE security exchange. Information \& Computer Security Vol.24 No.5. pp.514-533

Forbes, Nl. (2009). Contingency planning for earthquakes in Asia. Journal of Business Continuity \& Emergency Planning Volume 3 Number 4

Hawkins. S M., Yen D. C., Chou, D, C .2000. Disaster recovery planning: a strategy for data security. Information Management \& Computer Security 8/5Snedaker, S. (2007). Business Continuity \& Disaster Recovery for IT Professionals. Syngress.

Shaluf Ibrahim Mohamed. 2017. Disaster types. Disaster Prevention and Management Vol. 16 No. 5, 2007 pp. 704-717

Sugiyono. (2016). Metode Penelitian: Kuantitatif, Kualitatif dan R\&D. Alfabeta

Wiboonratr, Montri, and Kosavisutte, K. (2009). Optimal Strategic Decision For Disaster Recovery. International Journal of Management Science and Engineering Management, Vol. 4 No. 4, pp. 260-269 


\section{Laman (Website)}

Badan Nasional Penanggulangan Bencana, Definisi dan jenis Bencana, www.bnpb.go.id/pengetahuan-bencana/definisi-dan-jenis-bencana

https://www.cnbcindonesia.com/market/20180513174543-17-14726/nasib-rupiah-kala-terorbom-merajalela

https://www.cnbcindonesia.com/market/20180513153314-17-14717/ledakan-bom-di-ri-danhantaman-pada-ihsg

https://tirto.id/saat-teror-bom-menggoyang-bursa-saham-cKrE

https://finance.detik.com/bursa-dan-valas/d-4021635/dampak-bom-dan-terorisme-bagi-pasar$\underline{\text { saham }}$

http://www.bnpb.go.id/pengetahuan-bencana/definisi-dan-jenis-bencana 